\title{
Harnessing the genetics of the modern dairy cow to continue improvements in feed efficiency ${ }^{1}$
}

\author{
M. J. VandeHaar, ${ }^{2}$ L. E. Armentano, $†$ K. Weigel, † D. M. Spurlock, $\ddagger$ R. J. Tempelman, ${ }^{*}$ and R. Veerkamp§ \\ *Department of Animal Science, Michigan State University, East Lansing 48824 \\ †Department of Dairy Science, University of Wisconsin, Madison 53706 \\ ‡Department of Animal Sciences, lowa State University, Ames 50011 \\ $\S$ Animal Breeding and Genomics Centre, Wageningen UR Livestock Research, PO Box 65, NL-8200 AB Lelystad, the Netherlands
}

\begin{abstract}
Feed efficiency, as defined by the fraction of feed energy or dry matter captured in products, has more than doubled for the US dairy industry in the past $100 \mathrm{yr}$. This increased feed efficiency was the result of increased milk production per cow achieved through genetic selection, nutrition, and management with the desired goal being greater profitability. With increased milk production per cow, more feed is consumed per cow, but a greater portion of the feed is partitioned toward milk instead of maintenance and body growth. This dilution of maintenance has been the overwhelming driver of enhanced feed efficiency in the past, but its effect diminishes with each successive increment in production relative to body size and therefore will be less important in the future. Instead, we must also focus on new ways to enhance digestive and metabolic efficiency. One way to examine variation in efficiency among animals is residual feed intake (RFI), a measure of efficiency that is independent of the dilution of maintenance. Cows that convert feed gross energy to net energy more efficiently or have lower maintenance requirements than expected based on body weight use less feed than expected and thus have negative RFI. Cows with low RFI likely digest and metabolize nutrients more efficiently and should have overall greater efficiency and profitability if they are also healthy, fertile, and produce at a high multiple of maintenance. Genomic technologies will help to identify these animals for selection programs. Nutrition and management also will continue to play a major role in farm-level feed efficiency. Manage-
\end{abstract}

\footnotetext{
Received September 5, 2015.

Accepted December 28, 2015.

${ }^{1}$ Presented as part of the ADSA Production Division Symposium: The Rumen and Beyond-Nutritional Physiology of the Modern Dairy Cow at the ADSA-ASAS Joint Annual Meeting, Orlando, Florida, July 2015.

${ }^{2}$ Corresponding author: mikevh@msu.edu
}

ment practices such as grouping and total mixed ration feeding have improved rumen function and therefore efficiency, but they have also decreased our attention on individual cow needs. Nutritional grouping is key to helping each cow reach its genetic potential. Perhaps new computer-driven technologies, combined with genomics, will enable us to optimize management for each individual cow within a herd, or to optimize animal selection to match management environments. In the future, availability of feed resources may shift as competition for land increases. New approaches combining genetic, nutrition, and other management practices will help optimize feed efficiency, profitability, and environmental sustainability.

Key words: dairy cattle, feed efficiency, genetics

\section{INTRODUCTION}

Modern taurine cattle were likely first domesticated from wild aurochs in the Middle Euphrates River Valley about 9000 BCE, and they arrived in northern Europe around 4000 BCE (Bollongino et al., 2012; Scheu et al., 2015). The wild auroch became extinct approximately 400 years ago, but its phenotype is documented (van Vuure, 2005). In comparison to the auroch, modern dairy breeds are likely more docile, thinner, and less muscular, and have greater milk-secretory capacity. Until modern times, selection was generally not purposeful, or if selection was based on observation and scientific thinking, it was generally based on observations of an animal's own phenotype. Paintings from almost 400 years ago, such as Aelbert Cuyp's Cows in a River (c. 1654), indicate that the external phenotype of the modern dairy cow predated modern scientific selection and management. Thus, without the aid of modern science, humans produced cattle that were essentially "modern."

In the last $100 \mathrm{yr}$, the productivity of dairy cattle has risen considerably due to scientific advances in many 
disciplines. Chief among these was the science of quantitative population genetics, which began in the 1930s and greatly accelerated the rate of change (Shook, 2006; Gianola and Rosa, 2015). Other advances were also important. Technological developments in milking equipment and computerized record-keeping enabled accurate identification of those cows producing the most milk. Advancements in reproductive technologies, such as artificial insemination, enabled the selected animals to produce multiple offspring. Advances in nutrition and management enabled animals to reach their genetic potential so that genetic differences could be detected. Modern computing enabled development of breeding values, more accurate ration balancing, and sophisticated management systems. Finally, developments in methods for research, education, and outreach enabled these scientific advances to occur and provided an effective means for dissemination and application on farms.

The bovine genome was first published in 2009 (Bovine Genome Sequencing and Analysis Consortium, 2009), the same year in which genomic selection began in the US dairy industry (Wiggans et al., 2011). On the one hand, the science of genomics is just one more step in a series of developments, and yet genomics has revolutionized animal breeding. Genotyping and genomic selection have already enabled more accurate selection with a dramatically reduced generation interval compared with conventional selection systems based on daughter performance (Hayes et al., 2009; VanRaden et al., 2009). Superior genotypes can be identified at birth, and through advanced reproductive techniques, multiple offspring can be produced in less than $2 \mathrm{yr}$. By increasing the accuracy and intensity of selection and shortening the generation interval, the rate of genetic progress for economically important dairy traits can be approximately doubled (Schefers and Weigel, 2012). Genomics also enables selection for new traits such as feed efficiency (Hayes et al., 2013; Pryce et al., 2014a). Eventually, management practices might be tailored specifically for genotypes or genotypes might be selected to match environments. In the past $20 \mathrm{yr}$, multitrait selection indexes have been developed and evolved, and now include not only productivity but also traits such as longevity, udder health, and fertility (VanRaden, 2004). Clearly, changes in the genetics of dairy cattle are now occurring faster than at any time in history. Undesirable side effects from intense selection for productive efficiency may occur without adequate forethought (Rauw et al., 1998). The critical question to consider is, "What animal traits should be selected to match future demands?"

Feed efficiency matters on farms because it has a major influence on farm profitability and environmental stewardship in the dairy industry. Dairy feed efficiency in North America has doubled in the past 50 yr, largely as a byproduct of selecting and managing cows for increased productivity (VandeHaar and St-Pierre, 2006; Capper et al., 2009). Increasing productivity results in a greater percentage of total feed intake being used for milk instead of cow maintenance. The USDA National Agricultural Statistics Service show that current average milk production of dairy cattle in the United States is $10,100 \mathrm{~kg} /$ cow per yr. Elite dairy cattle in the United States currently partition $>3$ times more feed energy toward milk than toward maintenance over their lifetime (VandeHaar and St-Pierre, 2006). Most of the gain in feed efficiency from increasing productivity, especially from selecting for production, has already occurred in well-managed herds with superior genetics, and the dairy industry must begin to focus more directly on increasing the amount of milk from each unit of feed or each unit of land. Several excellent reviews have been published recently on dairy feed efficiency and possible selection mechanisms to improve it; among them are Berry and Crowley (2013), Pryce et al. (2014b), and Connor (2015). In this paper, we will describe the views of our group of nutritionists and geneticists on the most important considerations for improving feed efficiency of the modern dairy cow. These include (1) selection for efficient genetics and (2) management to take advantage of the genetic potential of superior cattle.

\section{DEFINING FEED EFFICIENCY}

Feed efficiency is a complex trait for which no single definition is adequate. Generally, feed efficiency describes units of product output per unit of feed input, with the units generally being mass, energy, protein, or economic value. For dairy cattle, the major product is milk, but the energy or value of tissue captured cannot be neglected. Losses or gains of body tissue can result in misleading values for feed efficiency if the only product considered is milk. Feed efficiency should be considered over the lifetime of a cow and include all feed used as a calf, growing heifer, and dry cow and all products including milk, meat, and calves. The factors that could be used to define efficiency in the dairy industry are shown in Figure 1.

At the farm level, feed efficiency also should account for feed that is wasted by the cow or during harvesting, storing, mixing, or feeding and for products that are not suitable for human consumption. In addition, we should consider that feed efficiency is more complicated than just feed and product. At the farm level, economic efficiency is clearly a priority. Feed is a major expense for any dairy farm, so biological feed efficiency affects economic efficiency, but so does the economic value of 


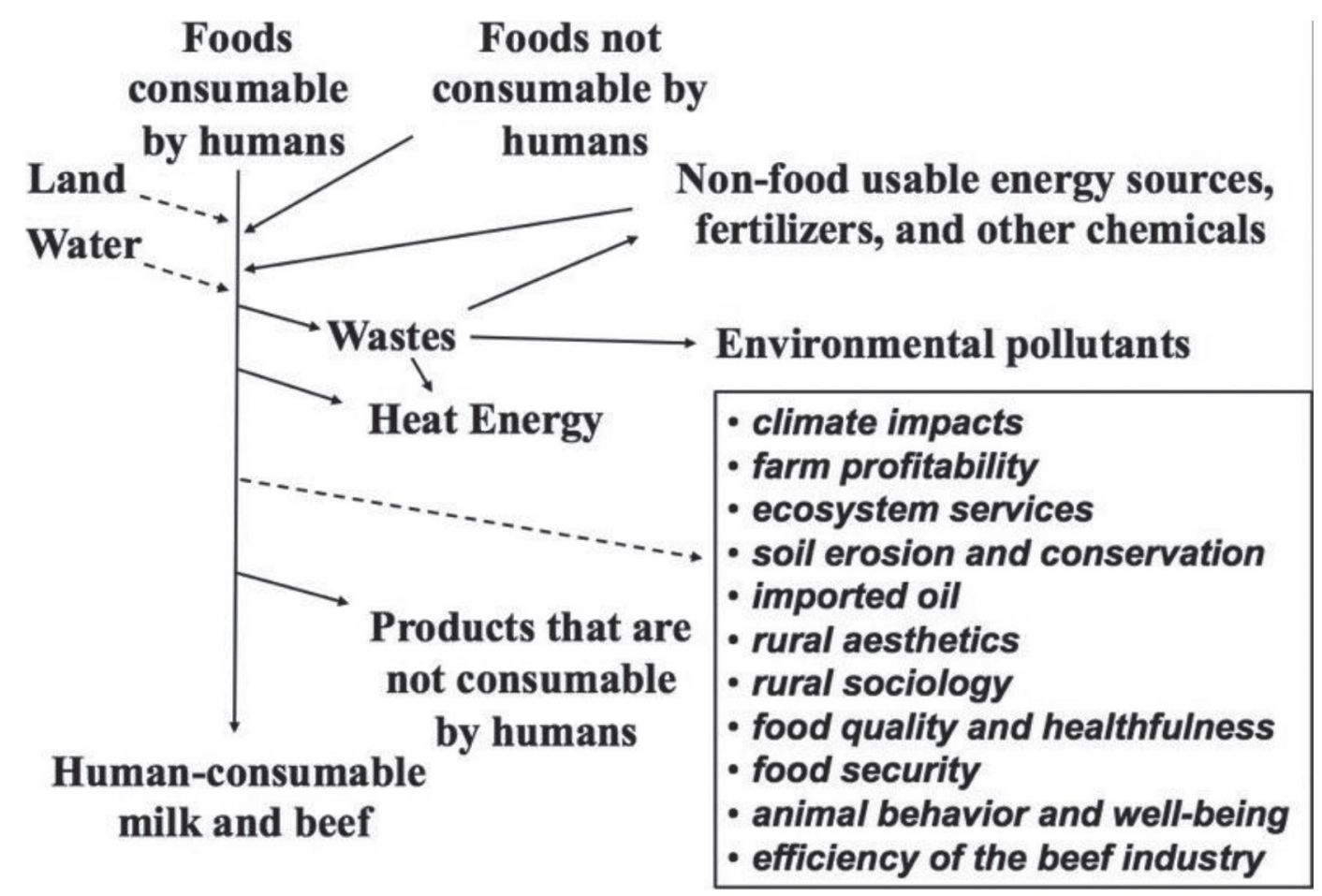

Figure 1. Factors to consider in defining feed efficiency. Solid lines indicate direct energy transfers, whereas dashed lines indicate other factors that should be considered in a holistic view of efficiency.

feed and milk components. However, other costs also are significant, and if they are fixed per cow, then they are essentially another farm maintenance cost that can be diluted out. Economic efficiency must be considered not per cow, but per farm, and most farms have constraints associated with barn space, land area, manure disposal, and labor (Mosheim and Lovell, 2009).

To define efficiency on a global scale, we should further consider inputs of human-consumable versus other foods, fossil fuels, water, and land, and outputs of greenhouse gasses, pollutants, fertilizers, and other products not used for human consumption. How we feed dairy cattle also affects ecosystem services, rural aesthetics and sociology, soil conservation, food quality and healthfulness, food security, animal well-being, the need for imported oil, and the beef industry (fewer dairy cows will increase the need for beef cows). Many of these considerations have been previously discussed (Oltjen and Beckett, 1996; VandeHaar and St-Pierre, 2006; Arriaga et al., 2009; Capper and Bauman, 2013; Connor, 2015).

Developing a metric that includes all relevant factors for feed efficiency would be difficult. Metrics for feed efficiency have been developed for feed and product mass (milk to feed ratio) and feed and product economic value (income over feed cost; feed cost per cwt milk). Protein is likely the most important component of milk, and protein is expensive to feed, so protein efficiency is important. However, energy is often the nutrient that generally limits milk production, and feed energy includes the energy of protein. Thus, for this paper, we will focus mostly on energetic efficiency. For the purpose of this discussion, the gross energy (GE) scheme can be simplified to that of Figure 2. More indepth reviews can be found (VandeHaar, 1998; NRC, 2001). Gross energy is the total chemical energy of a feed and is independent of how efficiently the cow uses it. Not all GE is useful because some of it is lost as the chemical energy in feces, gasses, and urine, and some is lost as the heat associated with the metabolic work of fermenting, digesting, and processing nutrients. The remaining chemical energy is known as net energy (NE). Some NE is used to support maintenance functions and is subsequently lost as heat. Some NE is the chemical energy of secreted milk or accreted body tissue and conceptus. For this paper, gross feed efficiency (GEff) is defined as the energy captured in products divided by the GE consumed by a cow in her lifetime.

Because GEff does not consider the source or cost of feed energy, nor the composition and value of the products, GEff is not very useful in making decisions about nutrition management. Gross feed efficiency could be 


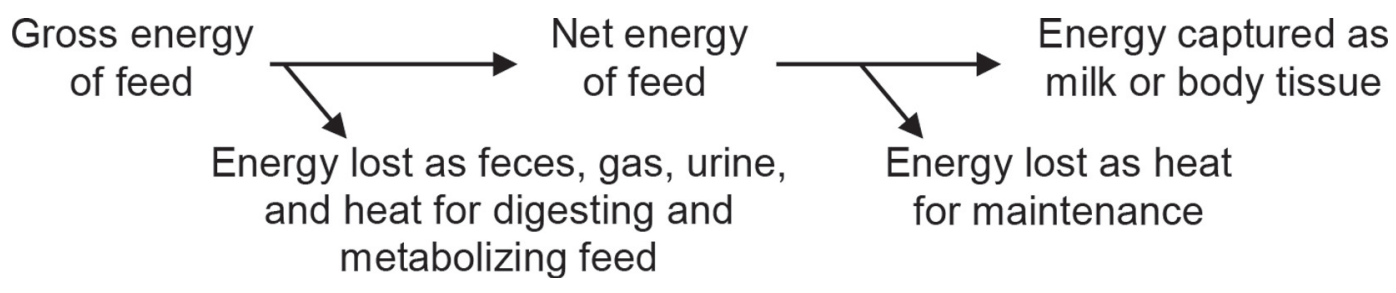

Figure 2. Energy flow in a cow.

useful in selecting animals for breeding, but it is highly correlated with milk yield, and this correlation must be appropriately accounted for in a selection program.

Feed efficiency can be assessed independently of production level by using residual feed intake (RFI), which is a measure of actual versus predicted intake for an individual (Figure 3). Residual feed intake is not very useful in making nutrition and management decisions on farms, but it shows promise as a tool for animal selection and has received considerable attention in the dairy industry (Veerkamp et al., 1995; Vallimont et al., 2011; Williams et al., 2011; Mäntysaari et al., 2012; Berry and Crowley, 2013; Connor, 2015; Pryce et al., 2015; Tempelman et al., 2015). Several ways to calculate RFI are possible, but usually RFI is determined statistically as the deviation of actual intake of a cow from the average intake of other cows that are fed and managed the same (Cohort) after adjusting for the major energy sinks of BW (related to maintenance), milk energy output (MilkE), and body energy change $(\triangle \mathrm{BE})$ as

$$
\begin{gathered}
\mathrm{DMI}_{\mathrm{i}}=\beta_{1} \times \mathrm{MilkE}_{\mathrm{i}}+\beta_{2} \times \mathrm{BW}^{0.75}{ }_{\mathrm{i}} \\
+\beta_{3} \times \Delta \mathrm{BE}_{\mathrm{i}}+\text { Cohort }+\mathrm{e}_{\mathrm{i}},
\end{gathered}
$$

where the residual error term $\left(e_{i}\right)$ is RFI. In this model, RFI includes error that is true variation among cows due to genetics, true variation that is due to permanent environmental effects, and variation from measurement error. Cows that eat less than expected have negative RFI, and thus are desirable when comparing animals for selection purposes as long as RFI is only seen as one factor to use in selecting for efficiency; selecting for high production relative to $\mathrm{BW}$ also must be an important selection criterion.

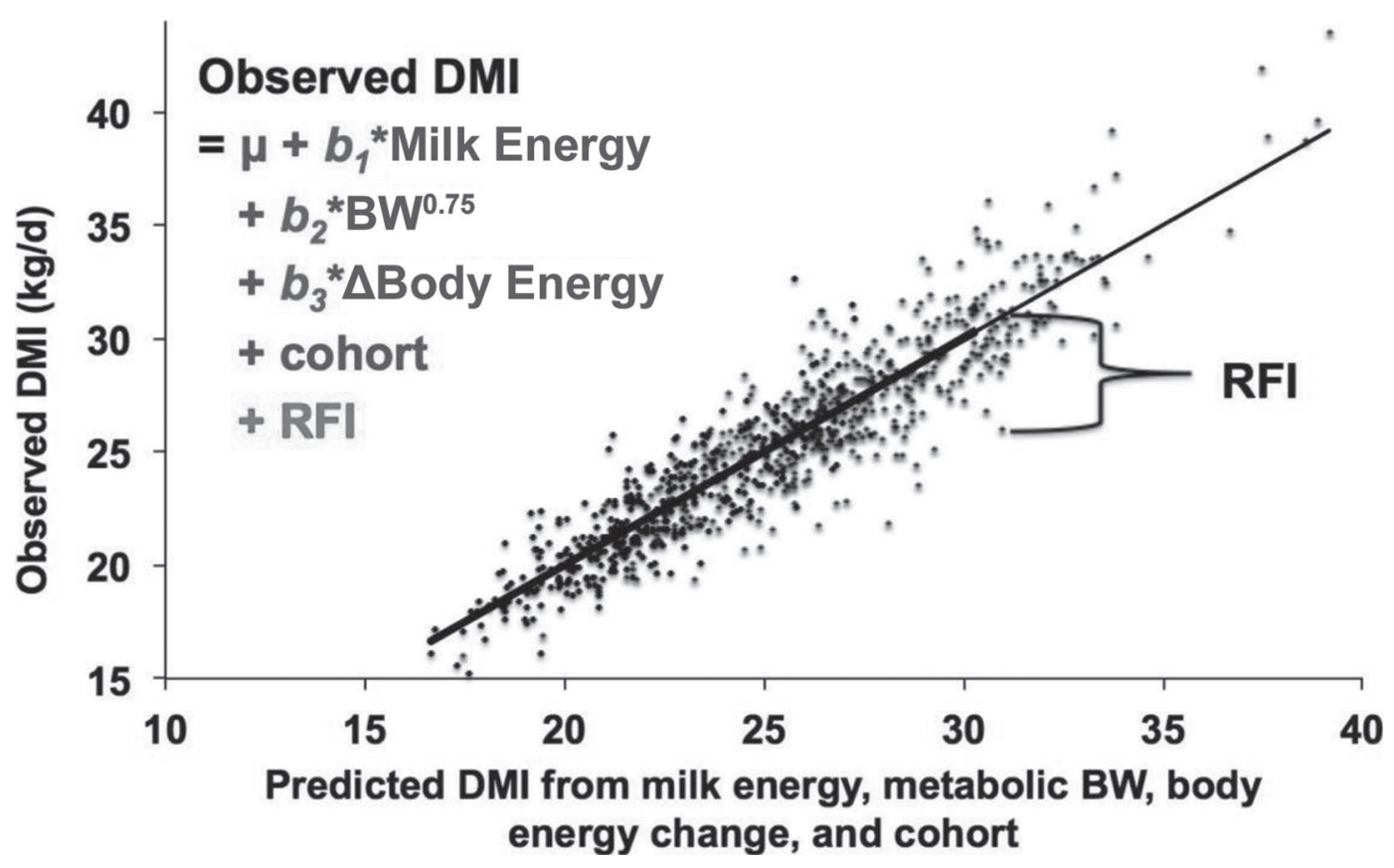

Figure 3. Residual feed intake (RFI) as a measure of feed efficiency. Cows that truly eat less than predicted are more efficient at converting feed gross energy to net energy or require less net energy for maintenance than expected based on their BW. 


\section{FEED EFFICIENCY IN THE MODERN DAIRY COW}

The modern dairy cow is already amazingly efficient. Milk synthesis is an efficient process compared with muscle deposition, and milk production accounts for the majority of the modern cow's energy flow. The obvious factors important for biological feed efficiency in lactating cows are feed intake, milk production, and BW change. Body weight is also important because it is a major determinant of a cow's maintenance requirement. Body condition score may alter the energy content of BW change. Environmental temperature and cow management can alter energy needs for other functions and voluntary feed intake. Diet composition influences the GE density of a diet, its losses as feces, methane, urine, and heat, and the cow's voluntary intake, milk production, and BW change, all of which alter feed efficiency. In addition, the portion of a cow's life spent as a heifer or dry cow will alter lifetime feed efficiency, as will feed wastage by the cow and the salability of her milk and meat.

The major components affecting feed efficiency can be divided into (1) those that alter maintenance and the dilution of maintenance, or the portion of NE that is captured in milk or body tissues instead of used for maintenance, and (2) those that alter the conversion of GE to NE, which include diet and cow effects. Variation among cows in converting GE to NE is essentially what is measured in RFI. Diet effects can be evaluated in nutrition models such as NRC (2001). These are described further below.

\section{Maintenance}

The typical Holstein cow has a maintenance requirement of $\sim 10$ Mcal of NE/d (equivalent to $\sim 25$ Mcal of GE and $\sim 6 \mathrm{~kg}$ of feed). This feed is used for life-sustaining functions such as circulation and respiration even when the cow is not producing milk, growing, working, or pregnant and is in her thermoneutral zone. Thirty years ago, Baldwin et al. (1985) divided whole-body maintenance energy expenditure into 3 major classes: 40 to $50 \%$ is work functions (liver, heart, kidney, nerve, and lung work), 15 to $25 \%$ is cell component synthesis (primarily protein and membrane lipids), and 25 to $35 \%$ is membrane transport (mostly associated with membrane potential maintenance and $\mathrm{Na}^{+}, \mathrm{K}^{+}$-ATPase). Considerable animal variation in maintenance energy requirement seems to exist and could be used to increase GEff (Baldwin et al., 1985). Using simulations of reported variations in 2 basal maintenance functions, ion pumping and protein turnover, McNamara (2015) reported that the maintenance NE requirement could vary by $20 \%$ among cows producing similar levels of milk.

For dairy cows, NRC (2001) used the formula 0.08 $\times \mathrm{MBW}$ to define a cow's NE requirement for maintenance. However, recent evidence suggests that the maintenance requirement per unit of metabolic BW (MBW; $\mathrm{BW}^{0.75}$ ) has increased over time for dairy cattle and now is $0.086 \times \mathrm{MBW}$ or perhaps even higher (Moraes et al., 2015). Apparently, we have selected dairy cattle that require more feed per unit of $\mathrm{MBW}$ just to survive, and dairy cattle now seem to require $\sim 10 \%$ more NE for maintenance per unit of MBW than do beef cattle (Freeman, 1975; Moraes et al., 2015; NRC, 2015). Reasons for the higher maintenance requirement per unit of MBW are likely that the body composition of dairy cattle differs from that of beef cattle, with less carcass relative to total BW, and less fat and more bone within the carcass (Nour et al., 1983; NRC, 2015). The fact that the maintenance requirement generated from models evaluating energy flow in newer studies with higher producing cows is greater than in older studies with lower producing cows or in beef cattle might also be due to some additional heat production associated with lactation being assigned to maintenance instead of to the heat increment of feeding. In our view, however, any "maintenance" costs that are associated with higher milk production should be assigned to production, not maintenance.

\section{Dilution of Maintenance}

If a cow eats at maintenance and produces no milk, her GEff is 0\%. Any extra feed above that needed for maintenance can be converted to milk or body tissues. If the cow eats twice as much feed, 20 Mcal NE or $2 \times$ maintenance, only half of her feed NE intake would be used for maintenance with the remaining half used for milk. As she eats even more feed, the portion used for maintenance becomes a smaller fraction of total feed intake; this "dilution of maintenance" increases efficiency, as has been known for a long time (Freeman, 1975; Bauman et al., 1985). Over the past 100 yr, GEff has more than doubled from the dilution of maintenance as productivity of the average North American dairy cow has increased with the use of genetic selection and artificial insemination, the use of better diets and feeding management, and the use of partitioning agents such as bST (Capper and Bauman, 2013). The maintenance requirement can also be directly decreased. A cow's energy requirement for maintenance has long been considered to be related to her MBW. Thus, smaller cows should have a smaller maintenance requirement.

As productivity and intake increase at constant BW, GEff increases from the dilution of maintenance; how- 
ever, the marginal increase in efficiency from diluting maintenance diminishes with each successive increase in feed intake (Figure 4, top panel). This relationship of efficiency to intake can be seen using data from 5,000 cows used in the study of Tempelman et al. (2015; Figure 4, bottom panel). These data demonstrate that as intake increases relative to body size, efficiency increases and plateaus at $\sim 40 \%$ and that there is considerable variation among cows (although some of the variation might be measurement error). This figure considers only the maintenance requirement of a cow while she is lactating; we recognize that maintenance costs should be considered on a lifetime basis by including a cow's maintenance as a heifer and during her dry periods, but no data are available with actual measures of lifelong maintenance.

\section{Is There an Optimal Level of Milk Production or Body Size?}

As productivity increases, efficiency increases but it cannot exceed the product of the conversion of GE to $\mathrm{ME}$ and the conversion of $\mathrm{ME}$ to milk NE after the maintenance requirement is supplied. In a recent reanalysis of data from the Beltsville energy laboratory, Moraes et al. (2015) reported conversions for feed energy values. Based on their study, the expected maximum efficiency is 35 to $40 \%$.

Using the projected curve for the dilution of maintenance, efficiency should begin to plateau as cows achieve about $5 \times$ maintenance. However, this projection is overly optimistic because as cows eat more, the percentage of feed that is digested is depressed (NRC, 2001; Huhtanen et al., 2009). At high intakes, the digestibility depression may even outweigh the dilution of maintenance and efficiency may decline with increased intake (VandeHaar, 1998). According to the equations used in the NRC (2001), efficiency peaks at $\sim 4 \times$ maintenance intake, which is $\sim 45 \mathrm{~kg}$ of milk ( $3.5 \%$ fat) per day for a $680-\mathrm{kg}$ cow. The NRC (2001) model likely discounts digestibility too much at high intakes, as shown in Huhtanen et al. (2009), and where efficiency peaks is not clear.

Feed efficiency on a lifetime basis requires accounting for body tissue gain and the feed consumed as a heifer and dry cow, which is 15 to $30 \%$ of the feed a cow eats during her lifetime. Based on the theoretical model of VandeHaar (1998), lifetime GEff is $\sim 20 \%$ for the current US average cow producing 10,000 kg of milk/yr. Many top US herds produce $15,000 \mathrm{~kg} / \mathrm{yr}$ and therefore have a lifetime GEff of $\sim 23 \%$ and likely are nearing maximum lifetime efficiency. Because these high-producing herds have mostly already diluted out maintenance, gains in feed efficiency will occur mostly from focusing on ways to save on feed inputs through nutritional grouping and new selection criteria that focus on efficiency. Many of the herds that are producing less are likely limited by feeding and management; in these herds, significant gains in feed efficiency can be captured by further diluting maintenance. One way to improve feed efficiency is to decrease the maintenance requirement by selecting cows that are smaller. However, the effect of multiples of maintenance on efficiency is likely the same whether
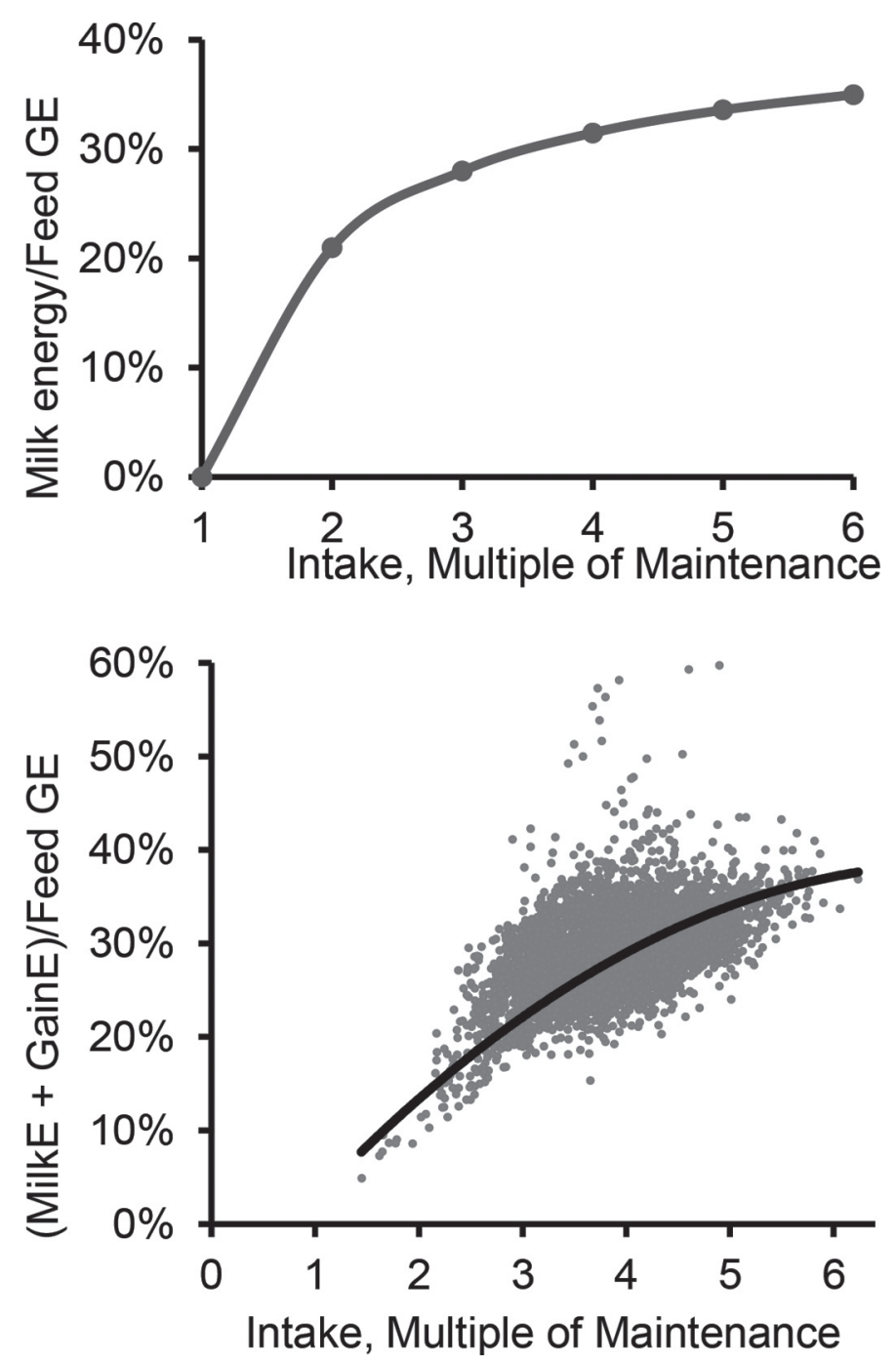

Figure 4. Expected (top panel) and measured (bottom panel) gross feed efficiency (GEff) as intake increases. Each intake multiple of maintenance will be about $10 \mathrm{Mcal}$ of $\mathrm{NE}_{\mathrm{L}}$ and 5 to $6 \mathrm{~kg}$ of feed DM. The top panel demonstrates that the increase in expected GEff diminishes with increasing intake. This expected response assumes no depression in digestibility as intake increases. Thus, the actual response should plateau even sooner and at a lower level. The bottom panel shows the measured GEff in $\sim 5,000$ mid-lactation Holstein cows assuming a feed gross energy (GE) value of $4.5 \mathrm{Mcal} / \mathrm{kg}$ (unpublished data from the study of Tempelman et al., 2015). The trend line for GEff in the bottom panel shows a diminishing response as GEff $=$ $-0.098+0.13 \times \mathrm{MM}-0.0094 \times \mathrm{MM}^{2}$, where $\mathrm{MM}=$ multiple of maintenance. 
we achieve more milk at a specific BW, or the same milk with smaller BW.

In general, over the past $50 \mathrm{yr}$, the body size of dairy cattle has increased concurrently with the increase in milk yield per cow. Most top sires in the AI industry were and still are larger than breed average (Hansen, 2000). Because of this, the US genetic base for body size traits in all dairy breeds must continually be adjusted up; as we will demonstrate later, this movement is counter to the goal of increasing feed efficiency in the dairy industry. Perhaps a relationship between size and milk yield is expected because some of the hormones that control lactation, such as somatotropin, also control growth (Etherton and Bauman, 1998). At one time, a genetic correlation between $\mathrm{BW}$ and milk production might have existed (Freeman, 1975). However, our latest analysis on 5,000 Holsteins in midlactation (using the data set of Tempelman et al., 2015) demonstrated no genetic correlation between BW and milk energy output (VandeHaar et al., 2014); moreover, BW was genetically correlated negatively with GEff. In a smaller subset of that data, Manzanilla-Pech et al. (2016) showed that milk energy output had zero or negative genetic correlations with BW and stature and inconsistent correlations across country for chest width and body depth. Already 40 yr ago, Freeman (1975; p. 34 ) pointed out that, "Heavier weight per se is not necessarily desirable, particularly when it is negatively correlated, phenotypically and genetically, with efficiency." Yet, we have continued to select for larger cows in the past decades. However, selecting for smaller cows likely will have less effect on GEff in the future than it would have had in the past, just like continuing to select for more milk will have less effect on GEff in the future, because maintenance is already considerably diluted in the modern high-producing cow, as shown in Figure 4. Moreover, based on this past data, more milk was more strongly correlated with greater GEff than was smaller body size. Thus, breeding for more milk seems a more important priority for greater GEff than does breeding for smaller BW. Nevertheless, smaller BW is a means to improve GEff with no concomitant negative consequence for milk production (unless smaller BW decreases digestibility), and the best way to improve efficiency is to use a linear index that favors greater milk production and smaller BW together.

\section{Conversion of GE to NE: Diet Effects}

The reader is referred to previous reviews on this topic (Smith, 1988; VandeHaar, 1998; Arriola Apelo et al., 2014), and we will make only a few comments. First, diet can significantly and directly alter GEff. If a cow eats to her energy requirements, then feed intake can be less with energy-dense diets and GEff will be greater. Energy density is altered by the GE value of feeds and the efficiencies of digesting and metabolizing the feed energy. Thus, supplemental fat increases GEff. In addition, feeds that are more digestible generally have greater NE densities, so including more starch and less fiber in a diet improves GEff. However, diets can also alter a cow's appetite (Allen, 2000; Allen and Piantoni, 2014), and therefore, because feed intake alters the dilution of maintenance, the effect of diet on GEff is not always easy to predict.

Second, using GEff as the metric for expressing feed efficiency when evaluating or reformulating diets seems wholly inadequate. If attaining the highest GEff was the goal in making feeding decisions, all dairy cattle would be fed diets high in grains and fats with minimal forage and byproduct feeds. In the last $20 \mathrm{yr}$, corn grain consumption by US livestock has decreased and the amount of corn byproducts available for feeding has increased (Klopfenstein et al., 2013). One of the values of the ruminant system is its ability to obtain energy from fibrous feeds, such as forages and high-fiber byproducts. From a global perspective, it seems that use of grains and fats in dairy diets should be limited to those times when they can be used to optimize production and health, and that forages and byproduct feeds high in fiber be fed to dairy cattle when possible, but this would decrease GEff. Thus, for purposes of efficiency, sustainability, and profitability, feeding to maximize GEff seems illogical. Other metrics, such as income over feed costs on a farm basis, the efficiency of using human-consumable foods, or milk per acre, seem more reasonable. For the purposes of animal selection, however, GEff and income over feed cost (IOFC) or milk per acre would be highly correlated.

\section{Conversion of GE to NE: Variation Among Cows}

Currently, DMI cannot be measured easily and routinely on individual cows in commercial farms. Using BW and production factors, feed intake can be predicted with reasonable accuracy across a wide range of production levels and used to predict GEff (Berry and Crowley, 2013). However, based on our data examining the GEff of cows compared with their level of production (Figure 4), efficiency varies considerably within a production level. The residual in the DMI prediction equation is RFI. Although part of RFI is error in measurements, some RFI is biological with a heritability of 0.17 based on 4,900 cows (Tempelman et al., 2015).

The basis for variation in RFI, or the part of DMI that cannot be easily justified, is not clear. This variation is associated mostly with the conversion of GE to NE, and thus is due to differences in digestibility, methane pro- 
duction, urinary energy losses, and metabolic pathways involved in processing nutrients and determining how much heat is produced above the animal's basal heat production for maintenance. Variation among cows in the actual maintenance requirement relative to $\mathrm{MBW}$ also contributes to RFI. Based on limited data, Herd and Arthur (2009) estimated that the contribution of various biological processes to RFI in cattle was $10 \%$ digestion, $37 \%$ tissue metabolism, $9 \%$ heat increment of feeding, $10 \%$ activity, $5 \%$ body composition, $2 \%$ feeding patterns, and $27 \%$ unknown; interestingly, these contributions are reasonably similar to the energy flows found in typical nonlactating cattle. Given that measurement error is part of RFI, this unknown contribution could be error and the true biological RFI among cows is smaller than the measured RFI. Thus, differences in digestive efficiency might be expected to contribute 10 to $20 \%$ of the differences in RFI among cows. Potts et al. (2015) measured digestibility and RFI in 110 lactating cows on 2 diets and concluded that digestibility accounted for up to $33 \%$ of the variation in the ability of cows to extract NE from feed.

The ruminal microbiome may play a role in GEff, and differences in the microbiome likely would affect digestive efficiency, methanogenesis, and the heat of fermentation. In support of this, Hernandez-Sanabria et al. (2012) identified 3 bacterial phylotypes that were associated with differences in RFI for steers fed a highenergy diet. Myer et al. (2015) also found that differences in the ruminal microbiome of growing steers were associated with differences in feed efficiency. However, others found no difference in methane production and methanogen rRNA as a percentage of total RNA in steers with very different residual gains (Freetly et al., 2015) and no difference in total methanogens but a less diverse methanogenic profile in cattle with greater feed efficiency (Zhou et al., 2010). A study with dairy cattle failed to find a difference in microbial populations of high and low RFI cows (Rius et al., 2012). However, the relative abundance of Ruminococcus flavefaciens was correlated with digestibility and was considered a possible explanation for differences in efficiency of grazing Irish Jersey compared with Holstein cows (Beecher et al., 2014). In the end, it is difficult to know what is causal in the relationship between the microbiome and digestibility. Weimer et al. (2010) exchanged the entire contents of the rumens of 2 pairs of cows with very different bacterial community composition. Host cows quickly reestablished original ruminal $\mathrm{pH}$ and VFA concentrations and the bacterial community displayed substantial host specificity. Thus, it seems likely that the cow controls the microbiome and the genetics of a cow alters her microbiome.

\section{DIRECTIONS FOR FURTHER IMPROVEMENTS IN FEED EFFICIENCY}

\section{Selecting Directly for Feed Efficiency}

Our initial analyses for dairy feed efficiency are based on 4,900 Holstein cows in North America, Scotland, and the Netherlands. Based on these data, the heritability of RFI in lactating cows is $\sim 0.17$. Previous studies, based on fewer cows, have estimated heritabilities for RFI of 0.01 to 0.33 (Van Arendonk et al., 1991; Ngwerume and Mao, 1992; Veerkamp et al., 1995; Vallimont et al., 2011). If RFI could be predicted based on pedigree or genomics, cows could be better selected and managed for maximal efficiency.

If selection for efficiency is to be realized by selection for RFI, RFI should be a repeatable trait across climate conditions, diets, lactation stage, and number, and stage of life. Data to date suggest that it is. Potts et al. (2015) fed 109 cows diets with 14 or 30\% starch in a crossover design and found the correlation for RFI of a cow when fed a high-starch diet with her RFI when fed a low-starch diet to be 0.7. This was similar to the correlation among weeks with no change in diet, suggesting that dietary starch and fiber content had little effect on a cow's relative ranking for efficiency. Based on our data and others, RFI also seems to be repeatable across lactations, and stages within a lactation (Connor et al., 2013; Tempelman et al., 2015). The RFI is also repeatable across stage of life, so that selection of animals based on their RFI as growing heifers was predictive of their RFI rank as lactating cows (Macdonald et al., 2014).

During the 20th century, genetic selection for milk production traits relied heavily on quantification of the phenotype in daughters of young sires; sires with outstanding daughters were deemed genetically superior. Although milk production traits are routinely measured on many commercial farms, feed intakes of individual cows are not known. Thus, direct selection for feed efficiency, independent of milk yield and body size, was not possible. In fact, the surest way to enhance efficiency in the past was to select for increased milk production to dilute out maintenance (Freeman, 1975). Genomic selection enables selection for new traits such as feed efficiency. In genomic selection, cattle are genotyped and the genotype of each SNP is correlated with the trait of interest. Each SNP is a marker for DNA around it, and although a single SNP may have little effect, the combined information from multiple SNP can be powerful. Excellent reviews on the methodology of genomic selection, especially for nongeneticists, are Hayes et al. (2010) and Eggen (2012). 
Initial findings of a genomic analysis on 2,900 Holsteins used in the data set of Tempelman et al. (2015) were presented in 2014 (Spurlock et al., 2014). They found 61,000 SNP accounted for $14 \%$ of the variance in RFI, with the top 10 SNP accounting for $7 \%$ of the genetic variance. Six of the 8 chromosomes harboring major QTL influencing RFI did not influence DMI, milk energy output, or BW, indicating the possibility that genes important for digestive or central metabolic functions might be involved. Other lines of evidence, such as studies showing variation in transcripts for metabolic genes and in activity of metabolic pathways, support the idea that cows vary in their underlying metabolism (McNamara, 2015). Continued advancements in the science of nutritional and genetical genomics will help us to integrate our understanding of basic biology with more empirical data. Someday we may be able to select for specific metabolic traits or to select genotypes to match environments.

Evidence that genomic selection for RFI can work in the dairy industry has been demonstrated by Davis et al. (2014). Genomically estimated breeding values (GEBV) for RFI were developed using data on intake and growth of Holstein heifers. Cows on commercial herds were genotyped and 100 cows in the top $10 \%$ for RFI and 100 cows in the bottom $10 \%$ for RFI based on genotypes were purchased and brought to a common facility. Milk production and BW of these cows were essentially the same, but RFI as lactating cows differed by $0.63 \mathrm{~kg} / \mathrm{d}$. The RFI measured as lactating cows was correlated with the GEBV for RFI during growth at $\sim 0.3$ within the high and low groups. This decrease in feed intake is equivalent to the decreased feed needed for maintenance in a cow weighing $80 \mathrm{~kg}$ less, based on $\mathrm{NE}_{\mathrm{M}}$ equal to $0.086 \times \mathrm{MBW}$ and a feed NE concentration of $1.6 \mathrm{Mcal} / \mathrm{kg}$.

The use of genomics in selection against RFI or DMI is already beginning in Australia (Pryce et al., 2015) and the Netherlands (Veerkamp et al., 2014) and will likely occur in North America in the near future. It is important to note that RFI is only part of feed efficiency. Selection for efficiency must also consider the optimal levels of milk production relative to BW. The approach used by Pryce et al. (2015) seems reasonable, with an index to select against body size and against RFI while also selecting for milk yield and composition. Moreover, improvements in feed efficiency must not occur at the expense of health and fertility of dairy cows. Thus, relationships among measures of feed efficiency, energy balance, production, and fitness traits must be carefully considered in breeding goals. Finally, productivity will remain a key to farm profitability because increased milk yield dilutes fixed costs of the farm.

At present, 2 approaches are being considered worldwide for selection against intake. One is to select against RFI. The heritability of RFI is $\sim 0.17$ with almost no genetic correlation with production traits or body size traits. Thus, RFI could be added to the selection index with minimal effect on weights for production and body size, although weights for fertility, health, and longevity might need adjustment if any of these are genetically correlated with RFI. Another approach is to select against DMI. The heritability of DMI is $\sim 0.37$ (de Haas et al., 2015), but it has a positive genetic correlation with several important traits, including BW and milk energy output. Thus, DMI could be added to the selection index, but it would have a large effect on the selection emphasis placed on production and size traits. Accurate estimates of genetic correlations with these traits, as well as with health, fertility, and longevity, would be needed. In practice, these 2 approaches are not that different, and in both cases, the idea is to select against unnecessary feed intake ( $\mathrm{Lu}$ et al., 2015). The ideal cow for the future is shown in Table 1. If animals are successfully bred and selected for enhanced conversion of GE to NE (selection against $\mathrm{RFI}$ ), reevaluation of their nutritional needs may be required.

Table 1. Breeding goals for the cow of the future

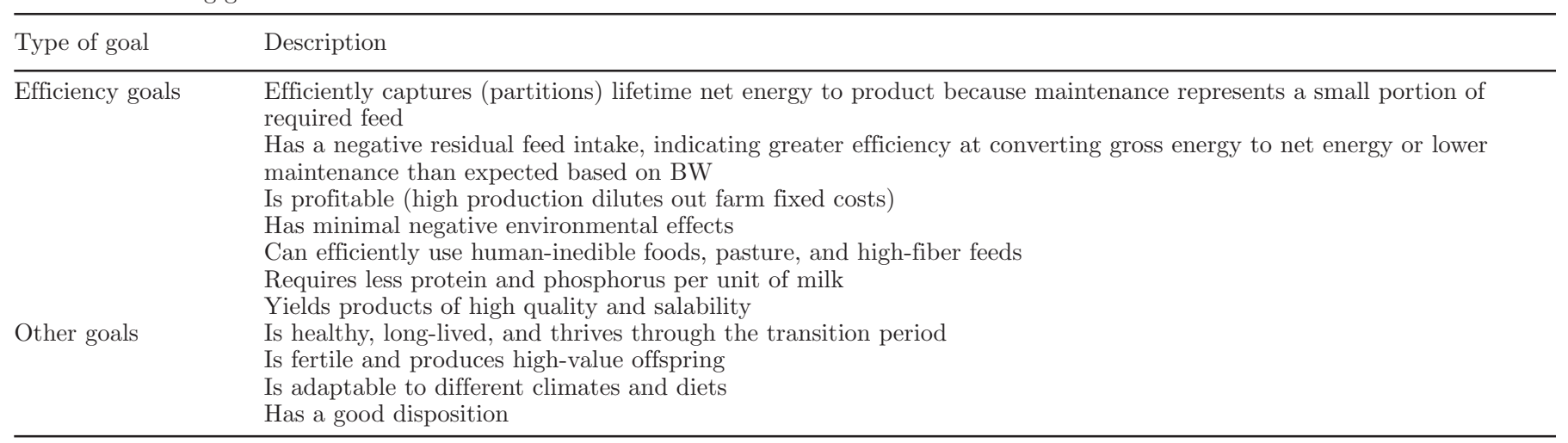




\section{Managing for Feed Efficiency}

The average US Holstein currently produces $~ 10,000$ $\mathrm{kg}$ of milk/yr and likely captures $\sim 21 \%$ of her lifetime GE intake as milk and body tissues. Whereas the increase in lifetime GEff with increased productivity diminishes at yields $>15,000 \mathrm{~kg} / \mathrm{yr}$; feed efficiency likely will not plateau for a cow with a mature BW of $625 \mathrm{~kg}$ until she reaches $>21,000 \mathrm{~kg}$ of $3.5 \% \mathrm{FCM}$, so increases in productivity will continue to improve efficiency for most North American dairy farms (VandeHaar, 1998). Using the model described in VandeHaar (1998), the effects of various management changes on efficiency were predicted. Increasing average daily milk production by $10 \%$ or increasing cow longevity from 3 to 4 lactations is expected to increase lifetime energetic efficiency $\sim 0.7 \%$. Reducing feed use by $2 \%$ with no change in milk production, by selecting against RFI or for smaller cows, or decreasing feed wastage, would improve energy efficiency by $\sim 0.5 \%$. Reducing the age at first calving by 2 mo, or reducing calving interval by $1 \mathrm{mo}$, would increase lifetime efficiency by $\sim 0.3 \%$. How cows are fed and managed at each stage of life can alter milk yield per day of life and thereby dilute maintenance and increase efficiency. These management changes promote similar improvements in the efficiency of converting feed protein to milk or body protein. However, the single biggest effect farms could make on efficiency of protein use is to simply quit overfeeding protein, as is often done in late lactation. Feeding cows past 150 d postpartum a diet with $2 \%$ less protein (15 vs $17 \%$ $\mathrm{CP}$ ) would increase efficiency of lifetime protein use by $1.3 \%$.

\section{Nutritional Grouping}

Nutrient requirements vary as lactation progresses, and the optimal diet for maximum efficiency and profitability changes as well (NRC, 2001; Allen and Piantoni, 2014). The widespread adoption of TMR feeding in the United States has improved productivity and efficiency because cows eat a consistent diet, but cows are less likely to receive a diet that matches their individual requirements. This is especially true if all lactating cows (other than perhaps the fresh cows) are fed the same TMR. Feeding a single TMR across lactation can never maximize production and efficiency. A single TMR is usually formulated for the higher producing cows and is more nutrient dense than optimal for cows in later lactation, resulting in inefficient use of most nutrients for these cows. In addition, although a single TMR is formulated for the high producers, it likely will not maximize milk for the herd because forages, grains, and expensive supplements cannot be allocated optimally.
In a survey of 400 farms, Contreras-Govea et al. (2015) found the 2 major constraints to nutritional grouping were that "It makes things too complicated" and "Low diets decrease milk yield." We propose that the job of a nutritionist is (1) to develop diets that consistently meet needs optimally for fresh, peak, and maintenance groups and demonstrate their benefits; (2) to use supplements, metabolic modifiers, feed additives, and low-cost alternative feeds to improve efficiency within groups; (3) to help farms make rules based on milk and BCS for moving cows and design systems to track cows; (4) to develop protocols for feeding an extra diet; (5) to consider computer feeders for high cows within a group; and (6) to make decisions regarding ration formulation based on cow responses.

The number of rations on any farm depends on many factors, but we recommend at least 3 based on feeding goals (Figure 5). The regulation of voluntary feed intake must be considered in diet formulation. Intake is likely limited by hepatic oxidation of fuels in fresh cows, but by rumen fill throughout much of the duration of lactation (Allen and Piantoni, 2014). In addition, fresh cows should be fed for optimal health and expensive supplements are warranted, whereas cows in peak lactation should be fed minimum fiber diets with plenty of digestible starch to maximize energy intake. Cows in later lactation should be fed to optimize milk and body condition; they should be fed less fermentable starch and more fermentable fiber to promote partitioning of nutrients toward milk instead of body tissues and thus minimize fattening (Allen and Piantoni, 2014; Boerman et al., 2015). The decision on when to switch cows from the early to late lactation diet should be based on body condition, parity, milk yield, and reproductive status. In addition, late lactation cows should be fed lower protein diets to maximize efficiency of protein use (NRC, 2001). Nutritional grouping and multiple TMR undoubtedly do increase capital, management, and labor costs; however, feeding cows according to requirements enhances production, efficiency, profitability, and sustainability of the industry (VandeHaar and St-Pierre, 2006). One approach might be to feed cows supplements individually using a computerized feeding system that recognizes cows and dispenses specific mixes at timed intervals throughout the day.

\section{Efficiency and Profitability}

Because lifetime production for most cows currently is only about $3 \times$ maintenance, greater milk yield per cow will continue to increase feed efficiency in the near future, and in turn, profit per cow. Data from commercial farms bears this out (Rodriguez et al., 2012). However, feed efficiency is only one factor that influ- 
ences profitability. Milk sales are the dominating factor in total farm profitability (Liang and Cabrera, 2015). Greater production per cow decreases the proportion of total farm expenses that are fixed; thus, even if we reach the optimal production per cow to maximize biological efficiency, economics still favors higher production per cow to dilute out farm fixed costs, provided feed costs are reasonable (VandeHaar and St-Pierre, 2006).

The disconnect between efficiency and profitability is especially important in considering breeding goals for milk, cow size, and RFI. Table 2 shows an example of possible results of breeding for more milk or for less feed consumption because of smaller body size or negative RFI in an example herd that currently has large cows $(800 \mathrm{~kg}$ of mature BW) and milk production at $13,070 \mathrm{~kg} / \mathrm{yr}$ at maturity. The magnitude of change for each breeding scenario was chosen to give the same effect on lifetime multiple of maintenance for milk and size goals and the same drop in feed consumption for the RFI goal. In this example, selection against feed intake by selecting for smaller cows increased lifetime IOFC by $\sim \$ 300$ per year, and selection against RFI increased lifetime IOFC by $\sim \$ 400$ per year (IOFC is less for small cows than low RFI cows because of differences in salvage value). However, selecting for greater milk yield to achieve the same GEff as the smaller cow increased lifetime IOFC by $\sim \$ 1,200$.

In our data set of 5,000 lactating Holstein cows eating on average at almost $4 \times$ maintenance, the genetic correlation of BW with GEff was negative but BW had zero genetic correlation with income over feed costs. In contrast, the genetic correlation of milk energy output was strongly positive with both GEff and IOFC. Thus, selection for milk should increase profits, whereas selection against cow size might have little effect on IOFC during peak lactation. This analysis, however, does not consider other effects of changes in cow size. For example, cow size is negatively correlated with longevity and adaptability to a barn (Hansen, 2000), and thus selection for small cows should improve whole farm profitability more than predicted based only on feed calculations. Another problem with bigger cows is that they require more space. The IOFC should always be considered on a whole farm basis, and if a farm can handle more cows, then the smaller cows will provide a greater advantage in IOFC than shown in Table 2. Thus, in concurrence with Hansen (2000), and on the basis of enhancing feed efficiency, profitability, animal welfare, and sustainability, we strongly recommend that the US dairy industry stop selecting for larger cows, and in-

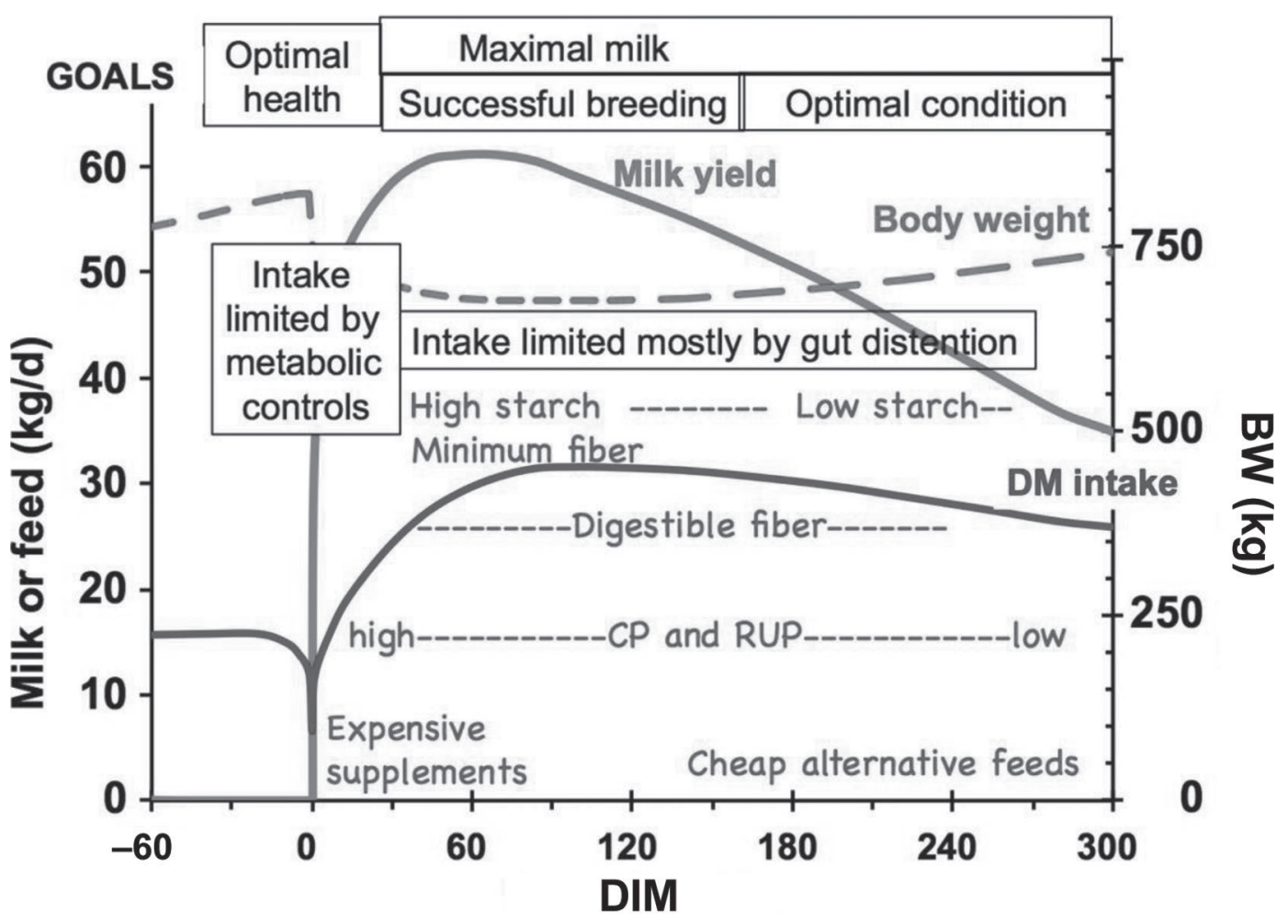

Figure 5. Considerations in nutritional grouping. Optimal formation of nutritional groups should consider goals for the cow, the primary drivers of appetite, the potential value of expensive supplements, and the effects of diet on nutrient partitioning between milk and body tissues. 
Table 2. Example of expected results from breeding for more milk or less feed

\begin{tabular}{|c|c|c|c|c|c|c|c|}
\hline Item & $\begin{array}{c}\text { BW at } \\
\text { maturity } \\
(\mathrm{kg})\end{array}$ & $\begin{array}{l}\text { Milk }{ }^{1} \text { yield } \\
\text { at maturity } \\
(\mathrm{kg} / \mathrm{yr})\end{array}$ & $\begin{array}{c}\text { Lifetime } \\
\text { multiple of } \\
\text { maintenance }\end{array}$ & $\begin{array}{l}\text { Captured } \\
\text { energy } \\
\text { (\% of GE) }\end{array}$ & $\begin{array}{l}\text { Lifetime } \\
\text { feed costs }{ }^{2} \\
(\$)\end{array}$ & $\begin{array}{l}\text { Lifetime } \\
\text { income }^{2} \\
\qquad \$)\end{array}$ & $\begin{array}{l}\text { Lifetime } \\
\text { income over } \\
\text { feed cost } \\
(\$)\end{array}$ \\
\hline Select for milk & 800 & 14,530 & 3.0 & 23.3 & 7,280 & 16,970 & 9,690 \\
\hline Select for size & 680 & 13,070 & 3.0 & 23.3 & 6,470 & 15,240 & 8,770 \\
\hline Select for $\mathrm{RFI}^{3}$ & 800 & 13,070 & 2.8 & 24.1 & 6,470 & 15,330 & 8,860 \\
\hline
\end{tabular}

${ }^{1}$ Assumes milk is $3.5 \%$ fat.

${ }^{2}$ Assumes milk at $\$ 0.40 / \mathrm{kg}$, cull cows at $\$ 1.80 / \mathrm{kg}$, and feed at $15 \phi / \mathrm{Mcal}$ of net energy $(\mathrm{NE} ; \sim 25 \phi / \mathrm{kg})$ for lactating cows and $12 \phi / \mathrm{Mcal}$ of $\mathrm{NE}$ for heifers and dry cows.

${ }^{3} \mathrm{RFI}=$ residual feed intake.

stead use an index that favors greater milk production and components, smaller cow size, and negative RFI as in Pryce et al. (2015). In this regard, it is imperative that the greater DMI required for maintenance of large cows not be forgiven in an index that includes selection against RFI or DMI.

\section{Efficiency and Stewardship}

Life cycle analysis is needed to consider the environmental effect from the broadest perspective and verify that increased productivity enhances environmental stewardship. Thomassen et al. (2008) compared conventional and organic Dutch dairy farms. Milk yield per cow was $40 \%$ greater for the conventional farms than the organic farms. When considering all inputs, conventional farms used $60 \%$ more energy and caused $50 \%$ more eutrophication per unit of milk produced, with no difference in climate change gasses. However, the organic farms required $40 \%$ more land; if this extra land spared by the conventional dairy had been used for biofuel production or put into native habitats, the conventional dairies would have had less negative effect on climate change. This is consistent with a study by Capper et al. (2009) showing that in the last $60 \mathrm{yr}$, the US dairy industry has decreased greenhouse gas emissions by $60 \%$ per unit of milk produced, mostly because of the enhanced feed efficiency from higher productivity. Thus, increased lifetime productivity (up to at least $4 \times$ ) increases efficiency, and increased efficiency generally is good for the environment-more people can be fed with less resources and less negative environmental impact. A recent FAO report (FAO, 2010) shows that even scientists who are not part of the US dairy science community agree with this view. Improving efficiency of milk production by using new technologies seems to be the responsible thing to do for the environment, at least in the foreseeable future, until average milk production exceeds $15,000 \mathrm{~kg} / \mathrm{yr}$.

\section{CONCLUSIONS}

We have made major gains in feed efficiency in the past $50 \mathrm{yr}$ as a byproduct of selecting, feeding, and managing cows for increased productivity, which dilutes maintenance. Average production is currently $\sim 10,000 \mathrm{~kg} / \mathrm{yr}$ and most cows have the genetics for even higher production. We must harness the genetics of the current dairy cattle population to improve feed efficiency even further and help feed people sustainably. Better feeding and management may be especially helpful for many lower producing herds to help them achieve at least $15,000 \mathrm{~kg} / \mathrm{yr}$. New genomic tools also should become available to select for cows that require less feed per unit of milk. To this end, we strongly recommend that the US dairy industry stop selecting for larger cows, and instead use an index that favors greater milk production and components, smaller cow size, and negative RFI.

\section{ACKNOWLEDGMENTS}

Funding for this research was provided by Agriculture and Food Research Initiative Competitive Grant no. 2011-68004-30340 from the USDA National Institute of Food and Agriculture (Washington, DC).

\section{REFERENCES}

Allen, M. S. 2000. Effects of diet on short-term regulation of feed intake by lactating dairy cattle. J. Dairy Sci. 83:1598-1624. http:// dx.doi.org/10.3168/jds.S0022-0302(00)75030-2.

Allen, M. S., and P. Piantoni. 2014. Carbohydrate nutrition: Managing energy intake and partitioning through lactation. Vet. Clin. North Am. Food Anim. Pract. 30:577-597. http://dx.doi.org/10.1016/j. cvfa.2014.07.004.

Arriaga, H., M. Pinto, S. Calsamiglia, and P. Merino. 2009. Nutritional and management strategies on nitrogen and phosphorus use efficiency of lactating dairy cattle on commercial farms: An environmental perspective. J. Dairy Sci. 92:204-215. http://dx.doi. org/10.3168/jds.2008-1304.

Arriola Apelo, S. I., J. R. Knapp, and M. D. Hanigan. 2014. Invited review: Current representation and future trends of predicting 
amino acid utilization in the lactating dairy cow. J. Dairy Sci. 97:4000-4017. http://dx.doi.org/10.3168/jds.2013-7392.

Baldwin, R. L., N. E. Forsberg, and C. Y. Hu. 1985. Potential for altering energy partition in the lactating cow. J. Dairy Sci. 68:33943402 .

Bauman, D. E., S. N. McCutcheon, W. D. Steinhour, P. J. Eppard, and S. J. Sechen. 1985. Sources of variation and prospects for improvement of productive efficiency in the dairy cow: A review. J. Anim. Sci. 60:583-592.

Beecher, M., F. Buckley, S. M. Waters, T. M. Boland, D. EnriquezHidalgo, M. H. Deighton, M. O'Donovan, and E. Lewis. 2014. Gastrointestinal tract size, total-tract digestibility, and rumen microflora in different dairy cow genotypes. J. Dairy Sci. 97:3906-3917. http://dx.doi.org/10.3168/jds.2013-7708.

Berry, D. P., and J. J. Crowley. 2013. Genetics of feed efficiency in dairy and beef cattle. J. Anim. Sci. 91:1594-1613.

Boerman, J. P., S. B. Potts, M. J. VandeHaar, M. S. Allen, and A. L. Lock. 2015. Milk production responses to a change in dietary starch concentration vary by production level in dairy cattle. J. Dairy Sci. 98:4698-4706. http://dx.doi.org/10.3168/jds.2014-8999.

Bollongino, R., J. Burger, A. Powell, M. Mashkour, J. Vigne, and M. G. Thomas. 2012. Modern taurine cattle descended from small number of near-Eastern founders. Mol. Biol. Evol. 29:2101-2104.

Bovine Genome Sequencing and Analysis Consortium. 2009. The genome sequence of taurine cattle: A window to ruminant biology and evolution. Science 324:522-528.

Capper, J. L., and D. E. Bauman. 2013. The role of productivity in improving the environmental sustainability of ruminant production systems. Annu. Rev. Anim. Biosci. 1:469-489. http://dx.doi. org/10.1146/annurev-animal-031412-103727.

Capper, J. L., R. A. Cady, and D. E. Bauman. 2009. The environmental impact of dairy production: 1944 compared with 2007. J. Anim. Sci. 87:2160-2167.

Connor, E. E. 2015. Invited review: Improving feed efficiency in dairy production: Challenges and possibilities. Animal 9:395-408. http://dx.doi.org/10.1017/S1751731114002997.

Connor, E. E., J. L. Hutchison, H. D. Norman, K. M. Olson, C. P. Van Tassell, J. M. Leith, and R. L. Baldwin VI.. 2013. Use of residual feed intake in Holsteins during early lactation shows potential to improve feed efficiency through genetic selection. J. Anim. Sci. 91:3978-3988.

Contreras-Govea, F. E., V. E. Cabrera, L. E. Armentano, R. D. Shaver, P. M. Crump, D. K. Beede, and M. J. VandeHaar. 2015. Constraints for nutritional grouping in Wisconsin and Michigan dairy farms. J. Dairy Sci. 98:1336-1344.

Davis, S. R., K. A. Macdonald, G. C. Waghorn, and R. J. Spelman. 2014. Residual feed intake of lactating Holstein-Friesian cows predicted from high-density genotypes and phenotyping of growing heifers. J. Dairy Sci. 97:1436-1445.

de Haas, Y., J. E. Pryce, M. P. L. Calus, E. Wall, D. P. Berry, P. Løvendahl, N. Krattenmacher, F. Miglior, K. Weigel, D. Spurlock, K. A. Macdonald, B. Hulsegge, and R. F. Veerkamp. 2015. Genomic prediction of dry matter intake in dairy cattle from an international data set consisting of research 9s in Europe, North America, and Australasia. J. Dairy Sci. 98:6522-6534. http:// dx.doi.org/10.3168/jds.2014-9257.

Eggen, A. 2012. The development and application of genomic selection as a new breeding paradigm. Anim. Front. 2:10-15.

Etherton, T. D., and D. E. Bauman. 1998. Biology of somatotropin in growth and lactation of domestic animals. Physiol. Rev. 78:745761.

FAO. 2010. Greenhouse gas emissions from the dairy sector-A life cycle assessment. P. Gerber, T. Vellinga, P. C. Opio, B. Henderson, and H. Steinfeld. Food and Agriculture Organization of the United Nations, Rome, Italy.

Freeman, A. E. 1975. Genetic variation in nutrition of dairy cattle. Pages 19-46 in The Effect of Genetic Variation on Nutrition of Animals. National Academy of Science, Washington, DC.

Freetly, H. C., A. K. Lindholm-Perry, K. E. Hales, T. M. BrownBrandl, M. Kim, P. R. Myer, and J. E. Wells. 2015. Methane production and methanogen levels in steers that differ in resid- ual gain. J. Anim. Sci. 93:2375-2381. http://dx.doi.org/10.2527/ jas.2014-8721.

Gianola, D., and G. J. M. Rosa. 2015. One hundred years of statistical developments in animal breeding. Annu. Rev. Anim. Biosci. 3:19 56. http://dx.doi.org/10.1146/annurev-animal-022114-110733.

Hansen, L. B. 2000. Consequences of selection for milk yield from a geneticist's viewpoint. J. Dairy Sci. 83:1145-1150. http://dx.doi. org/10.3168/jds.S0022-0302(00)74980-0.

Hayes, B. J., P. J. Bowman, A. J. Chamberlain, and M. E. Goddard. 2009. Invited review: Genomic selection in dairy cattle: Progress and challenges. J. Dairy Sci. 92:433-443. http://dx.doi. org/10.3168/jds.2008-1646.

Hayes, B. J., H. A. Lewin, and M. E. Goddard. 2013. The future of livestock breeding: genomic selection for efficiency, reduced emissions intensity, and adaptation. Trends Genet. 29:206-214. http:// dx.doi.org/10.1016/j.tig.2012.11.009.

Hayes, B. J., J. Pryce, A. J. Chamberlain, P. J. Bowman, and M. E. Goddard. 2010. Genetic architecture of complex traits and accuracy of genomic prediction: Coat colour, milk-fat percentage, and type in Holstein cattle as contrasting model traits. PLoS Genet. 6:e1001139 http://dx.doi.org/10.1371/journal.pgen.1001139.

Herd, R. M., and P. F. Arthur. 2009. Physiological basis for residual feed intake. J. Anim. Sci. 87(E. Suppl.):E64-E71.

Hernandez-Sanabria, E., L. A. Goonewardene, Z. Wang, O. N. Durunna, S. S. Moore, and L. L. Guan. 2012. Impact of feed efficiency and diet on adaptive variations in the bacterial community in the rumen fluid of cattle. Appl. Environ. Microbiol. 78:1203-1214.

Huhtanen, P., M. Rinne, and J. Nousiainen. 2009. A meta-analysis of feed digestion in dairy cows. 2. The effects of feeding level and diet composition on digestibility. J. Dairy Sci. 92:5031-5042. http:// dx.doi.org/10.3168/jds.2008-1834.

Klopfenstein, T. J., G. E. Erickson, and L. L. Berger. 2013. Maize is a critically important source of food, feed, energy and forage in the USA. Field Crops Res. 153:5-11. http://dx.doi.org/10.1016/j. fcr.2012.11.006.

Liang, D., and V. E. Cabrera. 2015. Optimizing productivity, herd structure, environmental performance, and profitability of dairy cattle herds. J. Dairy Sci. 98:2812-2823. http://dx.doi. org $/ 10.3168 /$ jds.2014-8856.

Lu, Y., M. J. VandeHaar, D. M. Spurlock, K. A. Weigel, L. E. Armentano, C. R. Staples, E. E. Connor, Z. Wang, N. M. Bello, and R. J. Tempelman. 2015. An alternative approach to modeling genetic merit of feed efficiency in dairy cattle. J. Dairy Sci. 98:6535-6551. http://dx.doi.org/10.3168/jds.2015-9414.

Macdonald, K. A., J. E. Pryce, R. J. Spelman, S. R. Davis, W. J. Wales, G. C. Waghorn, Y. J. Williams, L. C. Marett, and B. J. Hayes. 2014. Holstein-Friesian calves selected for divergence in residual feed intake during growth exhibited significant but reduced residual feed intake divergence in their first lactation. J. Dairy Sci. 97:1427-1435.

Mäntysaari, P., A.-E. Liinamo, and E. A. Mäntysaari. 2012. Energy efficiency and its relationship with milk, body, and intake traits and energy status among primiparous Nordic Red dairy cattle. J. Dairy Sci. 95:3200-3211. http://dx.doi.org/http://dx.doi.org/10.3168/ jds.2011-4685.

Manzanilla-Pech, C., R. F. Veerkamp, R. J. Tempelman, M. L. van Pelt, K. A. Weigel, M. J. VandeHaar, T. J. Lawlor, D. M. Spurlock, L. E. Armentano, C. R. Staples, M. Hanigan, and Y. De Haas. 2016. Genetic parameters between feed-intake-related traits and conformation in 2 separate dairy populations - the Netherlands and United States. J. Dairy Sci. 99:443-457. http://dx.doi. org/http://dx.doi.org/10.3168/jds.2015-9727.

McNamara, J. P. 2015. TRIENNIAL LACTATION SYMPOSIUM: Systems biology of regulatory mechanisms of nutrient metabolism in lactation. J. Anim. Sci. 93:5575-5585. http://dx.doi. org/10.2527/jas.2015-9010.

Moraes, L. E., E. Kebreab, A. B. Strathe, J. Dijkstra, J. France, D. P. Casper, and J. G. Fadel. 2015. Multivariate and univariate analysis of energy balance data from lactating dairy cows. J. Dairy Sci. 98:4012-4029. 
Mosheim, R., and C. A. K. Lovell. 2009. Scale economies and inefficiency of U.S. dairy farms. Am. J. Agric. Econ. 91:777-794.

Myer, P. R., T. P. L. Smith, J. E. Wells, L. A. Kuehn, and H. C. Freetly. 2015. Rumen microbiome from steers differing in feed efficiency. PLoS ONE 10:e0129174. http://dx.doi.org/10.1371/ journal.pone.0129174.

NRC. 2015. Nutrient Requirements of Beef Cattle. 8th ed. National Academy Press, Washington, DC.

NRC. 2001. Nutrient Requirements of Dairy Cattle. 7th rev. ed. National Academy Press, Washington, DC.

Ngwerume, F., and I. L. Mao. 1992. Estimation of residual energy intake for lactating cows using an animal model. J. Dairy Sci. 75:22832287. http://dx.doi.org/10.3168/jds.S0022-0302(92)77989-2.

Nour, A. Y. M., M. L. Thonney, J. R. Stouffer, and W. R. C. White Jr. 1983. Changes in carcass weight and characteristics with increasing weight of large and small cattle. J. Anim. Sci. 57:1154-1165.

Oltjen, J. W., and J. L. Beckett. 1996. Role of ruminant livestock in sustainable agricultural systems. J. Anim. Sci. 74:1406-1409.

Potts, S. B., J. P. Boerman, A. L. Lock, M. S. Allen, and M. J. VandeHaar. 2015. Residual feed intake is repeatable for lactating Holstein dairy cows fed high and low starch diets. J. Dairy Sci. 98:4735-4747. http://dx.doi.org/10.3168/jds.2014-9019.

Pryce, J. E., O. Gonzalez-Recio, G. Nieuwhof, W. J. Wales, M. P. Coffey, B. J. Hayes, and M. E. Goddard. 2015. Hot Topic: Definition and implementation of a breeding value for feed efficiency in dairy cows. J. Dairy Sci. 98: http://dx.doi.org/10.3168/jds.2015-9621. In press.

Pryce, J. E., O. Gonzalez-Recio, J. B. Thornhill, L. C. Marett, W. J. Wales, M. P. Coffey, Y. de Haas, R. F. Veerkamp, and B. J. Hayes. 2014a. Short communication: Validation of genomic breeding value predictions for feed intake and feed efficiency traits. J. Dairy Sci. 97:537-542. http://dx.doi.org/10.3168/jds.2013-7376.

Pryce, J. E., W. J. Wales, Y. de Haas, R. F. Veerkamp, and B. J. Hayes. 2014b. Genomic selection for feed efficiency in dairy cattle. Animal 8:1-10. http://dx.doi.org/10.1017/S1751731113001687.

Rauw, W. M., E. Kanis, E. N. Noordhuizen-Stassen, and F. J. Grommers. 1998. Undesirable side effects of selection for high production efficiency in farm animals: A review. Livest. Prod. Sci. 56:15-33. http://dx.doi.org/10.1016/S0301-6226(98)00147-X

Rius, A. G., S. Kittelmann, K. A. Macdonald, G. C. Waghorn, P. H. Janssen, and E. Sikkema. 2012. Nitrogen metabolism and rumen microbial enumeration in lactating cows with divergent residual feed intake fed high-digestibility pasture. J. Dairy Sci. 95:50245034. http://dx.doi.org/10.3168/jds.2012-5392.

Rodriguez, L. A., G. Bethard, D. Tomlinson, and M. McGilliard. 2012. Impact of milk yield, herd size, and feed efficiency on economic change between and within California dairies from 2006 through 2010. J. Anim. Sci. 90(E-Suppl.1). (Abstr.)

Schefers, J. M., and K. A. Weigel. 2012. Genomic selection in dairy cattle: Integration of DNA testing into breeding programs. Anim. Front. 2:4-9. http://dx.doi.org/10.2527/af.2011-0032.

Scheu, A., A. Powell, R. Bollongino, J.-D. Vigne, A. Tresset, C. Çakırlar, N. Benecke, and J. Burger. 2015. The genetic prehistory of domesticated cattle from their origin to the spread across Europe. BMC Genet. 16:54 http://dx.doi.org/10.1186/s12863-015$0203-2$.

Shook, G. E. 2006. Major advances in determining appropriate selection goals. J. Dairy Sci. 89:1349-1361. http://dx.doi.org/10.3168/ jds.S0022-0302(06)72202-0.

Smith, N. E. 1988. Alteration of efficiency of milk production in dairy cows by manipulation of the diet. Pages 216-231 in Nutrition and Lactation in the Dairy Cow. P. C. Garnsworthy, ed. Butterworth, London, United Kingdom.

Spurlock, D. M., R. J. Tempelman, K. A. Weigel, L. E. Armentano, G. R. Wiggans, R. F. Veerkamp, Y. de Haas, M. P. Coffey, E. E. Connor, M. D. Hanigan, C. Staples, and M. J. VandeHaar. 2014. Genetic architecture and biological basis of feed efficiency in dairy cattle. Proc. 10th World Congress of Genetics Applied to Livestock Production. https://asas.org/docs/default-source/ wcgalp-proceedings-oral/287_paper_10299_manuscript_1296_0 pdf?sfvrsn $=2$.

Tempelman, R. J., D. M. Spurlock, M. Coffey, R. F. Veerkamp, L. E. Armentano, K. A. Weigel, Y. de Haas, C. R. Staples, E. E. Connor, Y. Lu, and M. J. VandeHaar. 2015. Heterogeneity in genetic and nongenetic variation and energy sink relationships for residual feed intake across research stations and countries. J. Dairy Sci. 98:2013-2026. http://dx.doi.org/10.3168/jds.2014.8510.

Thomassen, M. A., R. Dalgaard, R. Heijungs, and I. de Boer. 2008. Attributional and consequential LCA of milk production. Int. J. Life Cycle Assessment 13:339-349.

Vallimont, J. E., C. D. Dechow, J. M. Daubert, M. W. Dekleva, J. W. Blum, C. M. Barlieb, W. Liu, G. A. Varga, A. J. Heinrichs, and C. R. Baumrucker. 2011. Heritability of gross feed efficiency and associations with yield, intake, residual intake, body weight, and body condition score in 11 commercial Pennsylvania tie stalls. J. Dairy Sci. 94:2108-2113. http://dx.doi.org/10.3168/jds.2010-3888.

Van Arendonk, J. A. M., G. J. Nieuwhof, H. Vos, and S. Korver. 1991. Genetic aspects of feed intake and efficiency in lactating dairy heifers. Livest. Prod. Sci. 29:263-275.

van Vuure, C. 2005. Retracing the Aurochs-History, Morphology and Ecology of an Extinct Wild Ox. Coronet Books Incorporated, Philadelphia, PA.

VandeHaar, M. J. 1998. Efficiency of nutrient use and relationship to profitability on dairy farms. J. Dairy Sci. 81:272-282. http:// dx.doi.org/10.3168/jds.S0022-0302(98)75576-6.

VandeHaar, M.J., Y. Lu, D. M. Spurlock, L. E. Armentano, K. A. Weigel, R. F. Veerkamp, M. Coffey, Y. de Haas, C. R. Staples, E. E. Connor, M. D. Hanigan, and R. J. Tempelman. 2014. Phenotypic and genetic correlations among milk energy output, body weight, and feed intake, and their effects on feed efficiency in lactating dairy cattle. J. Dairy Sci. 97(E-Suppl.):80.

VandeHaar, M. J., and N. St-Pierre. 2006. Major Advances in Nutrition: Relevance to the sustainability of the dairy industry. J. Dairy Sci. 89:1280-1291. http://dx.doi.org/10.3168/jds.S00220302(06)72196-8.

VanRaden, P. M. 2004. Invited review: Selection on net merit to improve lifetime profit. J. Dairy Sci. 87:3125-3131. http://dx.doi. org/10.3168/jds.S0022-0302(04)73447-5.

VanRaden, P. M., C. P. Van Tassell, G. R. Wiggans, T. S. Sonstegard, R. D. Schnabel, J. F. Taylor, and F. S. Schenkel. 2009. Invited review: Reliability of genomic predictions for North American Holstein bulls. J. Dairy Sci. 92:16-24.

Veerkamp, R. F., M. P. L. Calus, G. de Jong, R. van der Linde, and Y. De Haas. 2014. Breeding Value for Dry Matter Intake for Dutch Bulls based on DGV for DMI and BV for Predictors. Proc. 10th World Congress of Genetics Applied to Livestock Production. https://asas.org/docs/default-source/wcgalp-proceedingsoral/115_paper_8665_manuscript_206_0.pdf?sfvrsn=2.

Veerkamp, R. F., A. R. Cromie, and G. Simm. 1995. Variance-components for residual feed-intake in dairy cows. Livest. Prod. Sci 41:111-120.

Weimer, P. J., D. M. Stevenson, H. C. Mantovani, and S. L. C. Man. 2010. Host specificity of the ruminal bacterial community in the dairy cow following near-total exchange of ruminal contents. J. Dairy Sci. 93:5902-5912. http://dx.doi.org/10.3168/jds.2010-3500.

Wiggans, G. R., P. M. VanRaden, and T. A. Cooper. 2011. The genomic evaluation system in the United States: Past, present, future. J. Dairy Sci. 94:3202-3211. http://dx.doi.org/10.3168/jds.2010-3866.

Williams, Y. J., J. E. Pryce, C. Grainger, W. J. Wales, N. Linden, M. Porker, and B. J. Hayes. 2011. Variation in residual feed intake in Holstein-Friesian dairy heifers in southern Australia. J. Dairy Sci. 94:4715-4725. http://dx.doi.org/10.3168/jds.2010-4015.

Zhou, M., E. Hernandez-Sanabria, and L. L. Guan. 2010. Characterization of variation in rumen methanogenic communities under different dietary and host feed efficiency conditions, as determined by PCR-denaturing gradient gel electrophoresis analysis. Appl. Environ. Microbiol. 76:3776-3786. http://dx.doi.org/10.1128/ AEM.00010-10. 